\title{
Peperangan Proxy, Mozarab dan Cordova dalam Sejarah Umayyah II di Andalusia
}

\author{
Muhammad Affan \\ Mahasiswa Pascasarjana Prodi Sejarah Peradaban Islam \\ Universitas Islam Negeri (UIN) Sunan Gunung Djati, Bandung \\ mehmed.affan@gmail.com
}

\begin{abstract}
The following article aims to describe the proxy warfare, Mozarab and city of Cordova in the history of Umayyad II in Andalusia, Spain. The results of the study are expected to contribute historical-based thinking in the development of Islamic studies and social-humanities studies. Method used in this study is the method of historical research through literature review. From the study, it is concluded that Umayyad II prefers to align with the Byzantine on the basis of the political interests of power rather than the fraternal brethren of Muslims. Umayyad II is also more oriented towards Arabization than the Islamization of the Andalusian region as evidenced by the emergence of the Mozarab social class and the highly civilized city of Cordova. So it can be understood further that the presence of Umayyad II rule in Andalusia is not a direct cause of the spread of Islam in the region.
\end{abstract}

Keywords: proxy warfare, mozarab, cordova, Ummayad Andalusia.

\begin{abstract}
Abstrak
Artikel berikut bertujuan untuk menguraikan peperangan proxy, mozarab dan kota Cordova dalam sejarah Umayyah II di Andalusia, Spanyol. Hasil kajian diharapkan dapat memberi sumbangan pemikiran berbasis sejarah dalam pengembangan studi-studi Islam dan studi sosial humaniora. Metode yang dipergunakan dalam kajian adalah metode penelitian sejarah melalui kajian literatur. Dari kajian yang dilakukan, diperoleh kesimpulan bahwa Umayyah II lebih memilih beraliansi dengan Byzantine atas dasar kepentingan politik kekuasaan ketimbang persaudaraan sesama Muslim. Umayyah II juga lebih berorientasi pada usaha arabisasi daripada islamisasi wilayah Andalusia yang dibuktikan dengan kemunculan kelas sosial mozarab dan kota Cordova yang berperadaban tinggi. Sehingga dapat difahami lebih jauh bahwa kehadiran kekuasaan Umayyah II di Andalusia tidak menjadi sebab langsung penyebaran agama Islam di wilayah tersebut.
\end{abstract}

Kata kunci: peperangan proxy, mozarab, cordova, Umayyah Andalusia. 


\section{PENDAHULUAN}

Berakhirnya Kekhalifahan Umayyah menandai dimulainya kekuasaan Kekhalifahan Abbasiyah. Namun, Umayyah tidak benar-benar berakhir. Salah seorang cucu khalifah Umayyah kesepuluh, yang selamat dari pembunuhan tentara Abbasiyah, berhasil menyeberang ke Andalusia, Spanyol. Laki-laki ini, Abdul Rahman bin Mu'awiyah bin Hisyam, berhasil melakukan konsolidasi kekuatan dan mendirikan kembali Umayyah di Andalusia, Spanyol.

Jika pada awalnya Umayyah adalah sebuah lembaga kekuasaan yang menyebut dirinya sebagai Khalifah Rasulullah, setelah kehadiran Abbasiyah, Umayyah bukan hanya tergusur ke Andalusia melainkan harus merelakan posisi khalifah di ambil oleh Abbasiyah dengan gelar yang lebih tinggi, Khalifah Allah. Persaingan keduanya juga cukup unik. Jika pendahulu Umayyah mengambil sikap bermusuhan dan berperang melawan Byzantine, maka Umayyah di Andalusia mengambil kebijakan bersahabat dengan Byzantine.

Kebijakan politik tersebut diambil dengan pertimbangan untuk menciptakan proxy dalam permusuhan dengan Abbasiyah. Sementara Abbasiyah menjadikan Charlegmane sebagai sekutu mereka di Eropa untuk menghadapi Umayyah di Andalusia. Sehingga, hubungan permusuhan antara Umayyah Andalusia dengan Abbasiyah diwarnai oleh peperangan proxy.

Selain peperangan proxy, dua hal lain yang menonjol dalam sejarah Umayyah II di Andalusia adalah kehadiran kelas sosial bernama mozarab. ${ }^{1}$ Istilah mozarab sendiri mengacu kepada orang-orang Andalusia non-Muslim yang mengadopsi budaya Arab sebagai gaya hidup. Kehadiran mozarab menimbulkan kecemburuan pada penduduk Andalusia yang fanatik pada Kekristenan. Mozarab disalahfahami sebagai sebuah upaya islamisasi oleh penguasa Umayyah. Sehingga muncul aksi protes yang menimbulkan kekacauan didalam wilayah Umayyah Andalusia.

Hal menonjol lainnya dari kekuasaan Umayyah II di Andalusia adalah Cordova. Kota ini adalah representasi ketinggian peradaban Ummayah II yang pada masanya hanya bisa disaingi oleh Baghdad dan Konstantinopel. Keindahan arsitektur Mesjid Agung Cordova, perpustakaan Al Hakam II, Universitas Cordova dan Madinatul Zahra adalah simbol-simbol dari peradaban Umayyah di Andalusia yang kemudian hari menginspirasi Eropa.

Artikel berikut adalah artikel dengan objek kajian sejarah peradaban Islam klasik. Kajian literatur digunakan sebagai metode kajian dengan mengikuti langkah-langkah penelitian sejarah. Artikel ditulis dengan tujuan untuk menguraikan persoalan peperangan proxy, mozarab dan Cordova dalam bingkai sejarah Umayyah II di Andalusia.

${ }^{1}$ Lapidus menyebut kelas sosial ini sebagai Hispano-Arab, lihat Ira M. Lapidus, A History of Islamic Societies (Cambridge: Cambridge University Press, 1988) h. 310-311 
Mengingat, ancaman peperangan proxy juga sedang mengintai negerinegeri Muslim dunia, kajian ini diharapkan dapat memberi sumbangan pemikiran dan referensi dalam memahami proxy warfare berdasarkan fakta sejarah peradaban Islam sendiri. Selain itu, penjelasan mengenai fenomena mozarab diharapkan dapat membantu memahami perbedaan antara arabisasi dan islamisasi. Sementara, penjelasan mengenai ketinggian peradaban Cordova diharapkan dapat membangun kepercayaan diri orang-orang Islam untuk lebih bergiat membangun peradaban yang lebih baik dari sekarang.

\section{PEMBAHASAN}

\section{Peperangan Proxy}

Ketika Kekhalifahan Umayyah berhasil menguasai Andalusia, penguasa Eropa menganggap mereka sebagai musuh sekaligus penjajah. Keberhasilan pasukan Franka menahan gerak maju pasukan Ummayah di Poitiers menjadi sebuah peristiwa heroik yang dikenang Eropa sebagai keberhasilan membendung penyebaran Islam di Eropa. Padahal, gerak maju tersebut bukan dalam rangka penyebaran agama Islam. Gerak maju tersebut adalah sebuah usaha memperluas kekuasaan politik Umayyah. Namun, sejarah juga tidak bisa berbohong bahwa penaklukkan Andalusia oleh Umayyah telah ikut serta membawa Islam tersebar di Eropa.

Para penguasa Eropa memandang Umayyah sebagai representasi Islam ketimbang representasi Arab. Para penguasa Eropa yang mayoritas memeluk Kristen, membawa sentimen agama sebagai legitimasi permusuhan. Ketika kemudian Umayyah tidak melanjutkan gerak maju pasukannya ke Eropa Barat, penguasa Eropa Barat tetap menganggap mereka sebagai ancaman dan musuh yang suatu saat nanti harus ditaklukkan. Dengan kondisi ini, Umayyah di Andalusia selalu bermusuhan dengan penguasa Eropa yang Kristen.

Disisi lain, Umayyah juga bermusuhan dengan Byzantine. ${ }^{2}$ Permusuhan Umayyah dengan Byzantine adalah kelanjutan dari permusuhan Byzantine pada Nabi Muhammad SAW. Sikap permusuhan Byzantine ditunjukkan melalui dukungan mereka pada Syurahbil bin Amru Al Ghassani yang membunuh salah seorang utusan Nabi Muhammad SAW. Ketika kemudian sebuah ekspedisi militer dikirim untuk menghukum perbuatan tersebut, sang pelaku justru dibela Byzantine dengan mengirimkan pasukan untuk berperang melawan pasukan Nabi Muhammad SAW. Pertempuran tersebut, yang dalam sejarah Nabi Muhammad SAW dikenal sebagai pertempuran $\mathrm{Mu}^{\prime}$ tah, menjadi ronde pembuka kontak fisik antara orang-orang Islam dengan Byzantine. ${ }^{3}$

${ }^{2}$ Di negeri-negei Muslim, Byzantine lebih dikenal sebagai Kekaisaran Romawi Timur

3Ibnu Hisyam, Sirah Nabawiyah Jilid. 2, terj. Fadli Bahri (Jakarta: Darul Falah, 2014) h. 348, 592; lihat juga Abu Ja'far Muhammad Bin Jarir Ath Thabari, Shahih Tarikh Ath Thabari Jilid. 2, terj.Beni Hamzah, Solihin. (Jakarta: Pustaka Azzam, 2011) h. 443-448; lihat juga Mahdi Rizqullah 
Ketika Umayyah menjadi lembaga kekuasaan yang mengklaim sebagai Khalifah Rasulullah, institusi pemerintahan itu memiliki tanggung jawab besar untuk melindungi orang-orang Islam dari ancaman Byzantine. Oleh sebab itu, selama kekuasaan Kekhalifahan Umayyah, ibukota Byzantine, Konstantinopel diserang setidaknya tiga kali. Fakta sejarah ini menunjukkan bagaimana bentuk permusuhan antara Umayyah dengan Byzantine. Dengan demikian, Umayyah sebagai lembaga kekhalifahan memiliki paling tidak dua musuh besar, Byzantine dan Frank.

Seiring berjalannya waktu dan munculnya kekecewaan pada pemerintahan Kekhalifahan Umayyah, gerakan Abbasiyah muncul untuk menghentikan kekuasaan Umayyah. Keberhasilan gerakan Abbasiyah meruntuhkan Kekhalifahan Umayyah diikuti dengan kematian massal anggota keluarga dan kerabat kekhalifahan. Bahkan, makam para Khalifah Umayyah ikut dibongkar sebagai bentuk sasaran kemarahan gerakan Abbasiyah. Hanya makam Umar bin Abdul Aziz yang selamat dari pembongkaran.

Gerakan Abbasiyah juga berusaha berusaha menghabisi sisa-sisa kekuatan yang pro Umayyah ke seluruh wilayah kekuasaan dunia Muslim. Salah seorang cucu Hisyam, Khalifah Ummayah kesepuluh, Abdul Rahman bin Mu'awiyah bin Hisyam adalah anggota keluarga Ummayah yang dicari oleh tentara-tentara Abbasiyah. Abdul Rahman berhasil menyelamatkan diri dari Syam menuju Mesir. Di Mesir, ia berlindung secara nomaden dari satu kota ke kota lainnya, sampai akhirnya ia dapat menyeberang menuju Andalusia.

Kedatangan Abdul Rahman ke Andalusia bukannya tanpa perhitungan. Bagaimanapun juga, ia adalah buronan Abbasiyah. Andalusia akan memberinya perlindungan lebih baik ketimbang Syam maupun Mesir. Abdul Rahman sendiri berniat untuk menjadikan Andalusia sebagai pondasi membangun Umayyah kembali. Ia tiba di Andalusia pada thaun $755 \mathrm{M}$.

Bersama pasukannya, Abdul Rahman bergerak menuju Cordova. Ia mengalahkan gubernur Andalusia saat itu, Yusuf Al Fihr. Gubernur yang kalah tersebut melarikan diri dan membuat kekacauan sepanjang pelariannya hingga tewas di Toledo pada 759 M. Tapi Abbasiyah juga tidak menghendaki Andalusia jatuh ke tangan Abdul Rahman. Khalifah Abbasiyah, Al Mansur, yang tidak ingin wilayah Andalusia menjadi tempat berdirinya Umayyah baru, mengangkat seorang gubernur untuk menguasai Andalusia. ${ }^{4}$

Abdul Rahman berhasil mengatasi gubernur Abbasiyah tersebut. Sang gubernur, yang bernama A'la bin Mughits dihukum pancung dan kepalanya yang diawetkan dikirim kepada Al Manshur. Al Manshur menerima kiriman tersebut

Ahmad, Biografi Rasulullah: Sebuah Studi Analitis Berdasarkan Sumber-Sumber Yang Otentik, terj. Yessi H.M Basyaruddin (Jakarta: Qisthi Press, 2009) h. 684-689, 715

${ }^{4}$ David Levering Lewis, The Greatness of Al Andalus, terj. Yuliani Liputo (Jakarta: Serambi, 2012) h. 302-303 
dengan mengucap syukur. ${ }^{5}$ Abbasiyah kemudian terlibat dalam propaganda terhadap para mantan pengikut Abdul Rahman yang kecewa. Penyebabnya adalah sharing power yang tidak memuaskan. Kekecewaan tersebut kemudian berbuah menjadi pemberontakan pada kekuasaan Umayyah yang baru saja berdiri. Abdul Rahman berhasil mengatasi pemberontakan itu, namun ia harus bekerja keras untuk memastikan keberlangsungan hidup kekuasaannya tersebut.

Abdul Rahman sadar bahwa ide untuk mengklaim jabatan kekhalifahan, mesti masih dimungkinkan, tidak akan cukup populer bagi kekuasaan yang baru ia bangun. Bagaimanapun juga, Abbasiyah telah menguasai bagian terbesar dari wilayah Kekhalifahan Umayyah, meliputi Syam, Hijaz, Mesir dan Iraq. Sehingga, jabatan kekhalifahan menjadi lebih logis untuk diklaim oleh penguasa Abbasiyah.

Meski demikian, Abbasiyah sedikit merubah konsep jabatan kekhalifahan. Jika para pemimpin Umayyah menggunakan gelar Khalifah Rasulullah, maka para pemimpin Abbasiyah menggunakan gelar Khalifah Allah. Bisa jadi, perubahan gelar ini adalah salah satu cara Abbasiyah untuk menghindarkan Abdul Rahman melanjutkan klaim dari leluhurnya sebagai Khalifah Rasulullah. Dengan penggunaan gelar baru, Khalifah Allah, yang maknanya lebih tinggi daripada Khalifah Rasulullah, maka pemimpin Abbasiyah akan menjadi penguasa terbesar dan tertinggi didalam dunia Muslim. Sehingga, sekalipun Abdul Rahman memaksakan diri mengklaim jabatan Khalifah Rasulullah, gelar itu tidak akan bermakna bahwa Umayyah II lebih baik dan lebih tinggi didalam dunia Muslim.

Pada akhirnya, Abdul Rahman membangun Umayyah II di Andalusia sebagai sebuah emirat, dimana ia adalah amir pertamanya. Abdul Rahman mengambil Cordova sebagai ibukota Umayyah II. Dari Cordova, Abdul Rahman memperkokoh pemerintahannya dengan menyiapkan angkatan bersenjata yang kuat. Ia merekrut tentara dari orang-orang Berber yang dibayar. Jumlah tentara yang dilatih untuk melindungi Ummayah II sekitar 40.000 orang. ${ }^{6}$ Sebuah jumlah yang cukup besar untuk ukuran abad pertengahan. Angkatan bersenjata ini dibutuhkan oleh Umayyah II untuk mempertahankan diri dari musuh-musuh yang siap menerkamnya.

Ketika Umayyah II baru saja berdiri, Charlegmane mewarisi kekuasaan Frank bersama saudaranya Carloman. Ketika Carloman meninggal dunia, Chrlegmane menajdi penguasa tunggal bagi Frank. Kekuasaanya kemudian diinisiasi Paus sebagai Kekaisaran Roma yang baru. Meski pada faktanya, kekuasaan itu tidak ada hubungannya sama sekali dengan Kekaisaran Roma yang lama, inisisasi itu pada dasarnya adalah sebuah respon Paus di Roma yang berbeda pandangan keagamaan dengan Katolik Ortodoks yang di anut Romawi Timur. Dengan dukungan Paus pada Charlegmane, secara otomatis Roma baru ini bermusuhan dengan Byzantine.

${ }^{5}$ Phillip K. Hitti, History Of The Arabs, terj. Cecep Lukman Yasin, Dedi Slamet Riyadi (Jakarta: Serambi, 2008) h. 645. Sumber Hitti adalah Ibn Al Quthiyah, h. 33-34 dan Al Maqqari, Jilid I, h. 215. 'Ibid, h. 646 
Bagi Charlegmane, Umayyah adalah juga musuh, meskipun telah bertransformasi hanya menjadi sebuah emirat. Latar belakang sejarah Umayyah yang coba merangsek jauh ke Eropa Barat adalah salah satu pemicu permusuhan tersebut. Charles Martel yang menahan gerak maju Ummayah di Poitiers pada 732 M, adalah leluhur Charlegmane. Kemenangan leluhur Charlemagne tersebut, akan selalu diingat sebagai sebuah kisah heroik orang-orang Frank melindungi Eropa Barat dari ancaman Umayyah. Oleh sebab itu, meski Umayyah II telah mengalami perubahan konsep dan bentuk pemerintahan, kekuasaan itu tetap dianggap sebagai musuh tradisional Frank.

Charlemagne sendiri tidak membutuhkan waktu lama untuk menujukkan sikap permusuhannya pada Umayyah II. Undangan untuk bergabung kedalam sebuah konfederasi anti Umayyah II pada tahun $777 \mathrm{M}$, tidak dilewatkan begitu saja. Bahkan, hanya setahun setelah konfederasi tersebut diinisiasi, Charlegmane sudah bergerak menyusuri timur laut Spanyol menuju Zaragoza. Namun ia kembali ke ibukotanya setelah kota itu menolak membuka gerbang kota untuk bekerjasama dengannya. Alasan lain kembalinya Charlegmane ke ibukotanya adalah ancaman dari dalam wilayah teritorialnya sendiri yang memaksa ia untuk segera memadamkannya.

Perjalanan kembali itu tidak semulus perjalanan perginya. Ditengah jalan pulang, pasukannya diserang oleh orang-orang Basques dan Charlegmane menderita banyak kerugian jiwa dan materi. Usaha Charlegmane untuk melabrak Ummayah II menemui kegagalan. Namun bagi Abdul Rahman, gerakan pasukan Charlegmane memberi sinyal baginya untuk lebih berhati-hati. Paling tidak, dalam daftar musuh Ummayah II, kini tidak hanya ada nama Abbasiyah melainkan juga Franka.

Kehadiran Umayyah II disamping Kekhalifahan Abbasiyah telah mengubah peta geopolitik dunia Muslim untuk pertama kalinya. Situasi dan kondisi antara Umayyah II dan Abbasiyah sama sekali berbeda dengan situasi dan kondisi pada masa transisi Ali bin Abi Thalib dengan Mu'awiyah. Ketika Ali bin Abi Thalib wafat, Hasan bin Ali yang diangkat untuk meneruskan ayahnya, dengan sukarela menyerahkan kekuasaannya kepada Mu'awiyah. Sehingga dunia Muslim menjadi bersatu kembali secara politik. ${ }^{7}$ Unifikasi politik tersebut, meski menyisakan konflik-konflik kecil, masih menjadi simbol representasi politik orang-orang Islam kedalam sebuah lembaga saja. Sehingga, kekuatan-kekuatan diluar dunia Muslim juga menganggap bahwa Islam adalah sebuah kekuatan berbentuk kekhalifahan yang bersatu.

${ }^{7} \mathrm{Abu} J a$ 'far Muhammad Bin Jarir Ath Thabari, Shahih Tarikh Ath Thabari Jilid. 4E5, terj. Beni Hamzah, Solihin (Jakarta: Pustaka Azzam, 2011)h. 5; lihat juga Abu Ja'far Muhammad Bin Jarir Ath Thabari, Shahih Tarikh Ath Thabari Jilid. 3, terj. Beni Hamzah, Solihin(Jakarta: Pustaka Azzam, 2011) h. 762, dimana disebutkan bahwa Mu'awiyah baru disebut sebagai khalifah setelah Ali bin Abi Thalib wafat. 
Reunifikasi politik dunia Islam seperti masa Mu'awiyah tidak akan pernah terjadi. Cara Abbasiyah naik ke panggung kekhalifahan dunia Muslim dengan meruntuhkan Umayyah adalah latar belakang permusuhan keduanya. Umayyah II yang merupakan kelanjutan dari sisa kekuatan Kekhalifahan Umayyah mengambil sikap memusuhi Kekhalifahan Abbasiyah. Sementara itu, Abbasiyah juga mengambil sikap yang sama dengan memusuhi Umayyah. Latar belakang permusuhan keduanya jelas-jelas berlandaskan pada perbedaan pandangan politik. Kedua kekuatan itu, yang sesungguhnya merepresentasikan politik orangorang Islam, akan bersaing satu sama lain untuk saling menjatuhkan dan menghancurkan.

Bagi Umayyah II, Abbasiyah adalah musuh nomor satu dan Franka menjadi musuh nomor dua. Kedua musuh tersebut bukanlah kekuatan yang biasa. Bisa disebut keduanya adalah salah satu dari tiga raksasa dunia di abad pertengahan. Raksasa lainnya tentu saja Byzantine, musuh lama Umayyah. Persoalannya bagi Umayyah II adalah apakah Byzantine harus tetap menjadi musuh mereka. Abbasiyah dan Franka Roma sudah cukup besar sebagai musuh, jika masih ditambah dengan Byzantine, keberlangsungan hidup Umayyah II benar-benar akan terancam.

Jika mengacu pada kenyataan sejarah Umayyah yang bermusuhan dengan Byzantine, maka Umayyah II sebagai penerus Kekhalifahan Umayyah seharusnya juga menjadi musuh bagi Byzantine. Namun, kenyataannya sama sekali berbeda dengan Franka Roma yang segera menunjukkan sikap permusuhannya beberapa saat setelah Umayyah II berdiri. Byzantine sendiri justru menunjukkan sikap acuh tak acuh pada kehadiran Umayyah II di Andalusia.

Byzantine sepertinya masih fokus pada usaha untuk mengembalikan wilayah Syam yang jatuh ketangan Muslim sejak masa Khalifah Umar bin Khattab. Selama lebih satu abad, sejak lepasnya wilayah Syam, Byzantine tidak pernah berhasil merebut kembali wilayah tersebut dari tangan orang-orang Islam. ${ }^{8}$ Justru sebaliknya, orang-orang Islam telah berhasil melabrak ibukota kekaisaran mereka meski belum berhasil menguasainya. Rangkaian kekalahan Byzantine telah menjadikan kekaisaran tersebut sebagai superpower yang sakit. Sehingga, menjadi cukup realistis bagi Byzantine untuk menjadikan transisi kekuasaan dari Kekhalifahan Umayyah kepada Abbasiyah sebagai momentum untuk merebut kembali wilayah Syam dari tangan orang-orang Islam.

Dengan kondisi ini, secara otomatis Byzantine bermusuhan dengan Abbasiyah yang telah mewarisi bekas wilayah Kekhalifahan Umayyah. Permusuhan antara Byzantine dengan Abbasiyah tentu saja sebuah keuntungan politik bagi Umayyah II. Keuntungan politik itu menjadi bertambah ketika Umayyah II juga mengetahui bahwa antara Charlegmane dengan Byzantine terdapat perselisihan mengenai pandangan Kekristenan. Dengan demikian, 
Umayyah II mendapati kenyataan bahwa Byzantine juga memiliki musuh yang sama dengannya dalam bentuk kekuasaan Abbasiyah dan Frank.

Kehadiran musuh yang sama bagi Byzantine dan Umayyah II, akan segera dimanfaatkan oleh Umayyah II untuk menjadikannya sebagai teman. Paling tidak, antara Umayyah II dan Byzantine tidak saling serang. Kebijakan ini ditempuh untuk mengurangi ancaman dan tekanan pada eksistensi Umayyah II di Andalusia. Dua musuh, Franka dan Abbasiyah sudah cukup bagi Umayyah II.

Disisi yang lain, Charlegmane sendiri ternyata berteman dengan Khalifah Abbasiyah. Sehingga, kutub yang terbentuk diantara perselisihan mereka adalah Byzantine dan Umayyah II disatu kutub dan Abbasiyah dengan Franka Roma di kutub yang lain. ${ }^{9}$ Kedua kutub secara jelas tidak mencerminkan persekutuan berbasis agama. Kedua kutub hanya mewakili basis kepentingan politik masingmasing.

Jika melihat pada fakta sejarah yang berlangsung kemudian, Umayyah II akan menjadikan Byzantine sebagai proxy-nya dalam menghadapi Abbasiyah. Sementara Abbasiyah sendiri akan menggunakan Franka Roma sebagai proxy-nya memerangi Umayyah II. Oleh sebab itu, dalam sejarah Eropa kita akan melihat Franka Roma dan penguasa-penguasa Eropa lainnya yang beraliansi dengan Frank akan selalu berperang dengan Umayyah II. Bahkan ketika Umayyah II telah runtuh, peperangan masih akan berlanjut kepada kerajaan-kerajaan Muslim kecil di Andalusia.

Sementara itu, diwilayah Asia Tengah dan Asia kecil, sejarah akan mencatat peperangan-peperangan yang berlangsung antara Abbasiyah dengan Byzantine. Semua peperangan tersebut adalah hasil dari strategi peperangan proxy antara dua kutub yang masing-masing kutub diisi oleh kekuatan politik Islam berwujud Abbasiyah dan Umayyah II. Pandangan politik Abbasiyah dan Umayyah II yang berbeda, telah mewarnai geopolitik dunia abad pertengahan. Namun, konflik diantara Abbasiyah dengan Umayyah II tidak dapat difahami sebagai sebuah konflik didalam Islam, melainkan konflik diantara sesama orang Islam dalam kerangka perbedaan pandangan politik.

\section{Mozarab}

Sepanjang sejarah berdirinya, Umayyah II akan lebih banyak mengalami gangguan keamanan masif dari arah Eropa Barat. Sebagaimana dijelaskan diatas, hal ini adalah salah satu dampak dari peperangan proxy yang terjadi diantara Umayyah II dan Abbasiyah. Selain gangguan dari kekuasan-kekuasaan orang Kristen dari arah utara, Amir Ummayah II juga masih akan direpotkan oleh berbagai gangguan keamanan dari dalam wilayah teritorinya.

Meski demikian, peperangan proxy ini telah berdampak pada hampir tidak adanya kontak senjata langsung antara Amir Ummayah II di Andalusia dengan

9Phillip K. Hitti, History, h. 370 
Khalifah Abbasiyah di Baghdad. Pemberontakan bekas pengikut Abdul Rahman bin Mu'awiyah serta kedatangan A'la bin Mughits hanya dua dari beberapa keterlibatan Abbasiyah dalam usaha menggagalkan pendirian Ummayah II. Sementara, Abdul Rahman bin Mu'awiyah sendiri tercatat hanya sekali berusaha untuk menyerang dan menguasai kembali Syam yang telah menjadi bagian teritorial Abbasiyah. Usaha itupun urung ditengah jalan karena Abdul Rahman memilih kembali ke Andalusia disebabkan munculnya ancaman keamanan dari dalam wilayahnya sendiri. ${ }^{10}$

Meski demikian, Umayyah II tetap bercita-cita suatu saat kelak dapat mengambil kembali gelar kekhalifahan dari genggaman Abbasiyah. Para Amir Umayyah II kemudian terlibat dalam proyek-proyek sosial budaya dalam rangka persaingan dengan Kekhalifahan Abbasiyah. Jika Abbasiyah dengan ibukotanya Baghdad adalah mutiara yang menyaingi Konstantinopel, maka Cordova kemudian menjadi satu-satunya kota yang menjadi mutiara di Eropa. Di Cordova, Abdul Rahman bin Mu'awiyah mendirikan Mesjid Agung Cordova. Meski masih harus menghadapi beberapa pertempuran melawan penguasa-penguasa Kristen dari arah utara serta beberapa pemberontakan dari dalam negeri, Umayyah II masih cukup berhasil membangun sebuah peradaban Muslim yang maju di Eropa.

Ancaman keamanan yang cukup menggangu stabilitas kekuasaan Umayyah II terjadi pada masa amir ketiga, Al Hakam I. Ancaman itu yang dimulai pada sekitar tahun $805 \mathrm{M}$, berbentuk kerusuhan sipil yang berubah menjadi pemberontakan. Meski dapat diatasi oleh Al Hakam I, namun muncul dampak besar berupa eksodusnya lebih kurang delapan ribu keluarga dari wilayah Spanyol Muslim.

Pada masa amir keempat, Abdul Rahman II, mazhab Maliki mulai berkembang di Andalusia. Mazhab ini dibawa dan disebarkan oleh Yahya bin Yahya (w.849 M). Abdul Rahman II juga memberi perhatian pada astronomi, matematika, filsafat dan ilmu pengobatan. ${ }^{11}$ Pada masa Abdul Rahman II juga, Andalusia kedatangan seorang biduan terkenal dari Baghdad yang bermigrasi lalu menetap di Cordova. Biduan ini, bernama Ziryab dan berasal dari Persia. Ziryab adalah mantan biduan istana Khalifah Abbasiyah di Baghdad.

Ketika Ziryab tiba di Cordova, Abdul Rahman II tidak menyia-nyiakan kedatangannya. Abdul Rahman II memberinya gaji sekitar 3000 dinar pertahun. Dengan cara ini Abdul Rahman II berharap Ziryab dapat memperkaya peradaban Cordova hingga dapat menyaingi Baghdad. Upaya Abdul Rahman II cukup berhasil, dimana Ziryab kemudian bukan hanya menjadi biduan yang mempopulerkan Cordova. Ziryab adalah penyair, astronom dan ahli geografi

$10 \mathrm{Ibid}$, h. 645

${ }^{11}$ Wan Kamal Mujani, Ibnor Azli Ibrahim, "Contribution of Muslim Scholars to Astronomy in the Medieval Century of Andalusia" in Advances in Natural and Applied Sciences, 6(8): 1366-1369, (2012) h. 1367 
sekaligus. Ziryab juga menjadi seorang trend setter di Cordova. Dimana berkat kehadiran dan gayanya, orang-orang Cordova mulai minum dari wadah berbahan gelas. Sebelumnya orang-orang Cordova minum dari wadah berbahan logam. ${ }^{12}$

Cordova pada masa Abdul Rahman II, adalah masa dimana ibukota Umayyah II tersebut mulai memberi pengaruh kebudayaan yang kuat di wilayah Andalusia. Perilaku sosial dan budaya yang dikembangkan dari istana dan lingkungan istana Umayyah II diikuti tidak hanya oleh penduduk Emirat Umayyah II yang beragama Islam, melainkan juga oleh orang-orang Kristen. Namun, pengaruh kebudayaan ini hanya sebatas menjadikan para penduduk Andalusia yang Kristen menjadi ter-arab-kan. Apa yang terjadi di Andalusia adalah arabisasi bukannya islamisasi.

Orang-orang Kristen di wilayah Spanyol Muslim ini kemudian disebut sebagai mozarab, yaitu orang-orang yang mengikuti bahasa dan adat istiadat Arab. Namun orang-orang Spanyol yang fanatik pada Kekristenan justru salah faham dalam menilai menilai fenomena ini. Mereka justru menganggap bahwa Umayyah II sedang melakukan islamisasi melalui budaya. Sehingga, sebuah gerakan yang reaksioner muncul untuk memprotes fenomena mozarab.

Hasil dari gerakan itu adalah penghinaan kepada Nabi Muhammad SAW dan Islam oleh seorang pendeta Cordova bernama Perfectus pada sekitar tahun $850 \mathrm{M}$. Aksi penghinaan sang pendeta pun diganjar hukuman mati oleh penguasa Umayyah II. Uniknya, orang-orang Kristen dengan dipimpin oleh Uskup Cordova memberi gelar santo kepada pendeta tersebut.

Gesekan horizontal dengan membawa sentimen keagamaan di wilayah Spanyol Muslim tidak berhenti sampai disitu. Pendeta lainnya yang bernama Isaac, berpura-pura masuk Islam. Pendeta yang berpura-pura ini kemudian mengikuti jejak Perfectus dengan menghina Nabi Muhammad SAW dan Islam. Penguasa Umayyah II pun memberi hukuman yang sama kepada Isaac. Ia dihukum mati dengan cara dipancung. Oleh kalangan Kristen, Isaac kemudian juga diberi gelar santo.

Aksi menghujat Nabi Muhammad SAW dan menistakan agama Islam masih terus berlanjut di wilayah Spanyol Muslim. Sejarah mencatat setelah kedua peristiwa tersebut, paling tidak muncul sebelas aksi serupa dalam kurun waktu kurang dari dua bulan. Kesebelas aksi penistaan tersebut berakhir dengan hukuman mati. Kondisi demikian menjadikan stabilitas politik dan keamanan di Spanyol Muslim tidak cukup kondusif. Bahkan setelah amir Umayyah II berganti dari Abdul Rahman II kepada Muhammad I, kondisi ini masih berlanjut.

Muhammad I, kemudian mengambil kebijakan yang lebih tegas dengan menghukum mati aktor intelektual gerakan tersebut, yaitu pendeta Eulogius dan

12Phillip K. Hitti, History, h. 654-655 
Uskup Cordova. ${ }^{13}$ Namun tindakan hukum tersebut tidak menghentikan kekacauan berbasis sentimen agama tersebut. kekacauan masih terus berlanjut pada masa amir-amir berikutnya. Bahkan Al Mundzir, penerus Muhammad I; serta Abdullah yang merupakan penerus Al Mundzir, dituduh oleh pihak-pihak yang mengacau sebagai penguasa yang tidak toleran. Dengan bahasa lain, para amir Umayyah II dipaksa untuk bersikap toleran pada tindakan-tindakan yang menghujat serta menghina Nabi Muhammad SAW dan Islam.

Bersamaan dengan kekacauan yang disebabkan sentimen agama ini yang pada akhirnya didukung oleh para mozarab sendiri, muncul kekacauan lain yang juga ada hubungannya dengan sentimen agama. ${ }^{14}$ Seorang keturunan bangsawan Gothik yang bernama Umar bin Hafsun memimpin pemberontakan pada Umayyah II. Pemberontakan Umar bin Hafsun berlangsung selama masa pemerintahan Muhammad I, Al Mundzir, Abdullah dan Abdul Rahman III. Pemberontakan ini termasuk salah satu ancaman paling berbahaya bagi ibukota Umayyah II.

Umar bin Hafsun menggoyahkan Umayyah II dengan dukungan dari orang-orang Kristen. Meskipun ia seorang Muslim, orang-orang Kristen menganggapnya sebagai seorang pahlawan. Ada kemungkinan bahwa ia memang seorang Kristen yang menggunakan identitas Muslim. Indikasi ini dapat dilihat kemudian ketika ia memeluk agama Kristen dan mengganti namanya menjadi Samuel. ${ }^{15}$

Umar bin Hafsun alias Samuel kemungkinan juga mendapat bantuan dari Abbasiyah. Ia dilaporkan sempat menjalin komunikasi dengan Khalifah Abbasiyah. Umar bin Hafsun berharap Abbasiyah memberinya dukungan dan kompensasi sebagai gubernur Andalusia atas nama Abbasiyah ketika usaha pemberontakannya telah berhasil. Namun, ia gagal meski cukup berhasil merepotkan Umayyah II dengan mengisolasi ibukota Ummayah II di Cordova.

Umar bin Hafsun alias Samuel, terus menerus merongrong kekuasaan Umayyah II sampai masa Abdul Rahman III. Petualangan politik Umar bin Hafsun alias Samuel baru berakhir ketika ia meninggal dunia pada sekitar tahun 917 Masehi. Sampai kematiannya tersebut, ia telah memberontak pada Umayyah II selama lebih kurang 37 tahun.

Selain menghadapi anacaman Umar bin Hafshun alias Samuel. Pada saat yang hampir bersamaan, Umayyah II juga harus menghadapi ancaman dari utara dan selatan. Di utara, raja-raja Kristen dari Dinasti Leon berusaha mengambil alih wilayah-wilayah Umayyah II. Sementara di Selatan, Dinasti Fatimiyah yang telah

13Phillip K. Hitti, History, h. 655-657

14Fenomena ini sedikit menjelaskan bahwa sebenarnya kebanyakan penduduk Andalusia yang memeluk islam tidak benar-benar meemluk Islam melainkan hanya mengikuti gaya hidup dan budaya Arab

15Phillip K. Hitti, History, h. 659 
membangun aliansi dengan Umar bin Hafshun berusaha mengambil kontrol atas wilayah Andalusia.

Beberapa tahun sebelum berakhirnya pemberontakan Samuel, Abdul Rahman III telah menaklukkan Ekiya, Jaen, Elvira dan Sevila antara tahun 912-913 M. Ia kemudian berhasil menaklukkan Toledo pada tahun 923 M. Fatimiyah sendiri dikalahkan oleh Abdul Rahman III pada pertempuran tahun 929 M. ${ }^{16}$

\section{Cordova}

Ketika Abdul Rahman III naik kepuncak kekuasaan Umayyah di Cordova Spanyol, Abbasiyah sedang mengalami masa-masa kemunduran. Abdul Rahman sendiri masih harus menghadapi kepungan ancaman dari raja-raja Kristen di Utara, Dinasti Fatimiyah di Selatan, dan dari Umar bin Hafshun. Namun ia masih mampu mengatasi semua ancaman tersebut bahkan meluaskan wilayah kekuasaan Umayyah II.

Keberhasilan Abdul Rahman III, membuatnya percaya diri untuk menyatakan diri sebagai khalifah bagi dunia Muslim pada tahun 929 M. Abdul Rahman III kemudian mengambil gelar Al Khalifah An Nashir li Din Allah, yang berarti khalifah penolong agama Allah. ${ }^{17}$ Umayyah II, dimasa Abdul Rahman III telah berkembang jauh lebih baik daripada saat didirikan oleh leluhurnya Abdul Rahman bin Mu'awiyah bin Hisyam.

Ibukotanya, Cordova, adalah mutiara paling bersinar yang ketinggian peradabannya hanya dapat disaingi oleh Baghdad dan Konstantinopel. Penduduknya berjumlah paling tidak setengah juta jiwa. Sebuah angka yang besar untuk ukuran abad kesepuluh Masehi. Di Cordova, akan ditemukan setidaknya 130.000 keluarga, 3000 mesjid dan 28 kota satelit. ${ }^{18}$ Di ibukotanya ini, sang khalifah memiliki istana megah yang dibangun dengan biaya sekitar 300.000 dinar. Besarnya istana ini terlihat bangunannya yang memiliki panjang 1300 meter dan lebar 800 meter. Istana ini dikenal dalam sejarah sebagai Madinah Al Zahra. ${ }^{19}$

Kegemilangan Umayyah II pada masa Abdul Rahman III akan dilanjutkan oleh penerusnya Al Hakam II yang berkuasa pada tahun 961 sampai dengan 976 Masehi. Pada masa Al Hakam II, dunia mulai mengenal sebuah lembaga

16Joesoef Sou'yb, Sejarah Daulah Umayyah II Di Cordova (Jakarta: Bulan Bintang, 1977) h.

${ }^{17}$ Arif Septialona, "Perkembangan Islam Di Andalusia Pada Masa Abdurrahman III (An Nashir Liddinillah, 912-961 M)" dalam Tamaddun, Vol 1. No.1 (2016). h. 55

18 Yoyo Hambali, "Sejarah Sosial dan Intelektual Masyarakat Muslim Andalusia dan Kontribusinya bagi Peradaban Dunia" dalam Ilmu Ushuluddin, Vol. 3, No. 1, Januari (2016). h. 51. Bandingkan dengan Hitti yang menyebut angka 130.000 rumah; lihat Phillip K. Hitti, History, h. 669

${ }^{19}$ Athari Ibrahim Al Shuaibi, "Palaces In Andalusia And Iraq In the Islamic Era: A Historical Comparison Perspective" in International Journal of Heritage Architecture, Vol. 1, No. 3 (2017), h. 289 
pendidikan tinggi bernama Universitas Cordova. Kehadiran universitas ini-lah yang menjadikan Cordova dan Umayyah II lebih unggul dari Baghdad dan Abbasiyah.

Al Hakam II mengundang cendikiawan-cendikiawan untuk datang mengajar di Universitas Cordova. Salah satu dari cendikiawan itu adalah Ibnu Al Qutsiyah yang merupakan seorang sejarawan dengan kayanya yang terkenal Tarikh Iftitah Al Andalus. ${ }^{20}$ Popularitas Universitas Cordova telah memancing banyak penuntut ilmu untuk datang belajar ke tempat itu. para pelajar yang datang bukan hanya orang-orang Islam, melainkan juga orang-orang Kristen. Para pelajar juga tidak hanya berasal dari wilayah Andalusia, melainkan juga dari wilayah Afrika, Asia, dan Eropa lainnya.

Ketika Universitas Cordova telah mencapai popularitas dalam bidang pendidikan tinggi, Madrasah Nizhamiyah sendiri belum berdiri. Nizhamiyah sebagai sebuah lembaga pendidikan tinggi dalam Kekhalifahan Abbasiyah baru didirikan oleh Nizham Al Muluk pada sekitar tahun 1065-1067 M. Di sisi lain, pada sekitar tahun 972 M, cikal bakal Universitas Al Azhar di Kairo masih berupa Mesjid Agung yang baru mulai didirikan.

Hal lain yang membuat Cordova istimewa dan pantas merepresentasikan ibukota kekhalifahan dunia muslim yang baru adalah perpustakaannya. Di Cordova terdapat sebuah perpustakaan besar yang berisi tidak kurang dari 400.000 judul buku. Judul-judul buku tersebut disalin dalam sebuah katalog yang berjumlah 44 jilid. Dengan semua fasilitas pendidikan di Cordova, hampir seluruh penduduk kota itu bisa membaca dan menulis.

Jalanan di Cordova juga bagus dan rata. Malam harinya diterangi oleh lampu-lampu yang digantung didepan rumah-rumah penduduk yang berdiri di sepanjang jalan. Di Cordova juga terdapat banyak tukang tenun kain, yang jumlahnya diperkirakan sekitar 13.000 orang. Selain itu masih terdapat kilang besar untuk penyamakan kulit. ${ }^{21}$

Simbol ketinggian peradaban kota ini adalah sebuah karya arsitektur yang dibangun oleh Abdul Rahman I, yang diberi nama Mesjid Agung Cordova. Dari tempat itu, ketinggian peradaban Cordova ditransfer keberbagai wilayah Spanyol Muslim lainnya. Cordova menjadi sebuah pelita yang menyinari dan membawa Spanyol kepada kemakmuran. Pertanian tumbuh pesat dimana sistem pengairan dengan menggunakan kanal diperkenalkan. Beberapa komoditas yang sebelumnya tidak dikenal di Spanyol juga diperkenalkan dan mulai ditanam. Komoditas itu antara lain padi, kapas, aprikot, persik, delima dan tebu. Ummayah II juga mencetak mata uang dalam bentuk koin dinar emas dan koin dirham perak. Mata uang yang dicetak oleh Umayyah II ini digunakan bukan hanya 
didalam wilayah Spanyol Muslim, melainkan juga oleh negeri-negeri Kristen di utara Spanyol.

Apa yang kemudian menjadikan Umayyah II termasyhur di Eropa adalah produk-produk budaya mereka yang kemudian diadopsi dan dimodifikasi oleh dinasti-dinasti Muslim kecil sepeninggal keruntuhan Umayyah II. Hasil peradaban Muslim di Eropa tersebut-lah yang kemudian mewarnai dan memperkaya Eropa. Mendorong orang-orang Eropa untuk mengikuti jejak kemajuan peradaban Muslim diwilayah tersebut setelah reconquista yang menyedihkan.

Setelah Hakam II wafat, ia semestinya digantikan oleh putranya Hisyam II. Namun, disebabkan usianya yang masih cukup muda, ia hanya menjadi sebuah penguasa semu. Sosok yang menjalankan kekuasaan Umayyah II sesungguhnya adalah Muhammad bin Abi Amir yang kemudian akan dikenal sebagai Al Hajib Al Manshur. ${ }^{22}$

Al Hajib Al Manshur sesungguhnya adalah wazir dari Umayyah II. Berkat kecakapannya berpolitik, ia berhasil memposisikan diri sebagai penguasa dan pengatur pemerintahan Spanyol Muslim meski tidak menanggalkan Hisyam II dari jabatan khalifah. Di masa Al Hajib Al Manshur, Umayyah II masih berada dalam posisi gemilang. Ia membawa pasukan Umayyah II berperang dengan Leon, Castile dan Catalonia. Namun, Al Hajib Al Manshur juga yang mulai membawa Cordova ke arah kemunduran.

Al Hajib Al Manshur memerintahkan pemusnahan kitab-kitab filsafat dari perpustakaan Al Hakam. Pada tahun 978 M, Al Hajib Al Manshur membangun tempat tinggalnya yang disebut Madinah Al Zahirah diluar kota Cordova. Kehadiran istana baru ini, mengurangi pamor istana Madinah Al Zahra di Cordova. Ketika ia meninggal dunia pada 1002 M, Umayyah II tidak pernah berhasil mempertahankan kegemilangannya lagi. Kemunduran terus berlangsung sampai pada akhirnya, Hisyam III yang memerintah pada periode 1027-1031 M dikurung oleh bawahannya sendiri dalam sebuah ruang sempit disebelah Mesjid Agung Cordova. Hisyam III dikurung bersama putrinya yang masih bayi. Ia mengemis pelita dan roti untuk bayinya yang kedinginan dan kelaparan, sementara para menterinya sedang berunding untuk menetapkan penghapusan Umayyah II. ${ }^{23}$

\section{PENUTUP}

Penjelasan singkat diatas mengenai peperangan proxy, mozarab dan Cordova memberi informasi bahwa Umayyah II memilih untuk beraliansi dengan kekuasaan non-Muslim untuk menghadapi Abbasiyah yang sesungguhnya samasama Muslim. Apa yang dapat disimpulkan dan difahami dari penjelasan sejarah 
diatas adalah kepentingan politik para penguasa seringkali mengabaikan semangat ukhuwah islamiyah. Bahkan, sebuah persekutuan dengan non-Muslim dapat lebih erat terjalin ketimbang persahabatan dengan sesama Muslim hanya demi kepentingan politik. Sebuah ironi sejarah yang juga masih berlangsung sampai saat ini.

Penjelasan mengenai mozarab, memberi informasi bahwa Umayyah II lebih berorientasi pada usaha arabisasi dan bukannya islamisasi, yang uniknya justru disalahfahami oleh orang-orang non-Muslim Andalusia sebagai sebuah bentuk islamisasi. Fakta sejarah ini memberi pemahaman bahwa memang sejatinya Islam itu disebarluaskan oleh dakwah para ulama bukannya oleh kekuasaan politik. Lembaga politik lebih berperan dalam memberi perlindungan fisik pada orangorang Islam yang terancam oleh kekuasaan politik yang tidak menyukai kehadiran dan kemajuan orang-orang Islam.

Kehadiran sebuah lembaga kekuasaan yang merepresentasikan orangorang Islam juga dapat difahami sebagai institusi penggerak dan pelindung kebudayaan yang Islami. Hal ini tercermin pada ketinggian peradaban Cordova yang merupakan produk kebudayaan yang digerakkan dan dilindungi oleh penguasa Umayyah II di Andalusia. Namun, instabilitas politik juga yang berpotensi besar memundurkan dan menghancurkan peradaban itu sendiri. Sejarah Umayyah II di Andalusia memberi pelajaran mengenai semua ini.

\section{REFERENSI}

Ahmad, Mahdi Rizqullah. Biografi Rasulullah: Sebuah Studi Analitis Berdasarkan Sumber-Sumber Yang Otentik, terj. Yessi H.M Basyaruddin. Jakarta: Qisthi Press. 2009.

Al Shuaibi, Athari Ibrahim. "Palaces In Andalusia And Iraq In the Islamic Era: A Historical Comparison Perspective", International Journal of Heritage Architecture, Vol. 1, No. 3 (2017)

Ath Thabari, Abu Ja'far Muhammad Bin Jarir. Shahih Tarikh Ath Thabari Jilid. 2, terj.Beni Hamzah, Solihin. Jakarta: Pustaka Azzam. 2011.

Ath Thabari, Abu Ja'far Muhammad Bin Jarir. Shahih Tarikh Ath Thabari Jilid. 3, terj.Beni Hamzah, Solihin. Jakarta: Pustaka Azzam. 2011.

Ath Thabari, Abu Ja'far Muhammad Bin Jarir. Shahih Tarikh Ath Thabari Jilid. 4E5, terj.Beni Hamzah, Solihin. Jakarta: Pustaka Azzam. 2011.

Hambali, Yoyo. "Sejarah Sosial dan Intelektual Masyarakat Muslim Andalusia dan Kontribusinya bagi Peradaban Dunia", Ilmu Ushuluddin, Vol. 3, No. 1, Januari (2016).

Hisyam, Ibn. Sirah Nabawiyah Jilid. 2, terj. Fadli Bahri. Jakarta: Darul Falah. 2014. 
Hitti, Phillip K. History Of The Arabs, terj. Cecep Lukman Yasin, Dedi Slamet Riyadi. Jakarta: Serambi. 2008.

Lapidus, Ira M. A History of Islamic Societies. Cambridge: Cambridge University Press. 1988

Lewis, David Levering. The Greatness Of Al Andalus, terj. Yuliani Liputo. Jakarta: Serambi. 2012.

Septialona, Arif. "Perkembangan Islam Di Andalusia Pada Masa Abdurrahman III (An Nashir Liddinillah, 912-961 M)", Tamaddun, Vol 1. No.1 (2016).

Sou'yb, Joesoef. Sejarah Daulah Umayyah II Di Cordova. Jakarta: Bulan Bintang. 1977.

Wan Kamal Mujani, Wan kamal and Ibnor Azli Ibrahim. "Contribution of Muslim Scholars to Astronomy in the Medieval Century of Andalusia", Advances in Natural and Applied Sciences, 6(8): 1366-1369 (2012) 